\title{
Historein
}

Vol 4 (2003)

Public Histories

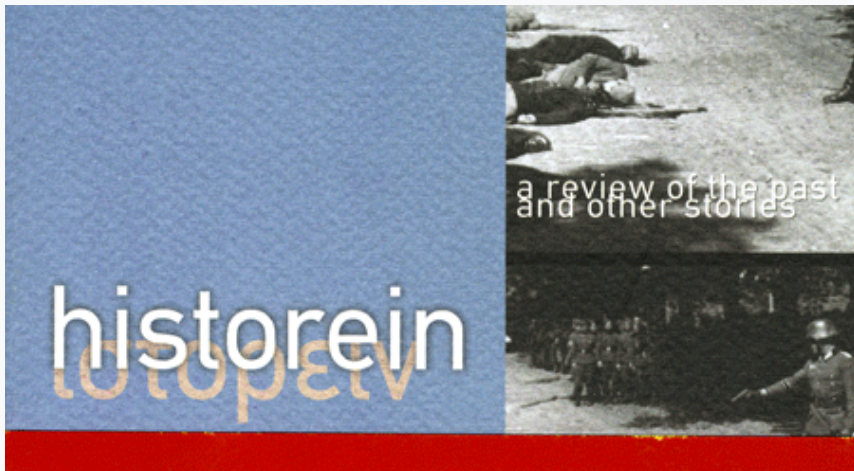

\section{Elli Scopetea (1950-2002) Member of the Academic Board of Historein}

\section{Historein Historein}

doi: $\underline{10.12681 / \text { historein.93 }}$

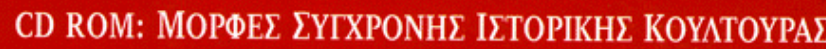

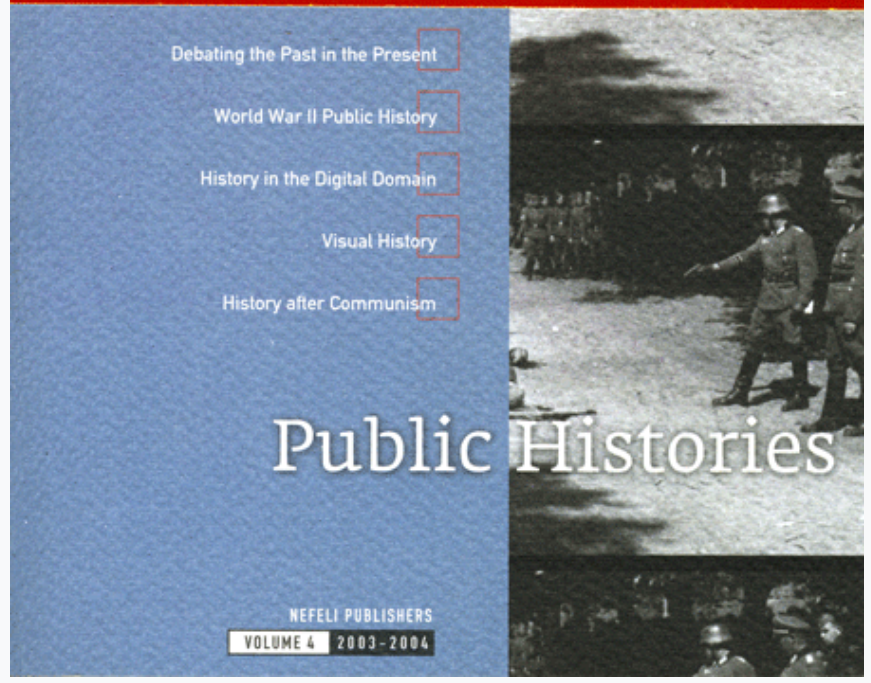

\section{Copyright @ 2012 , Historein Historein}

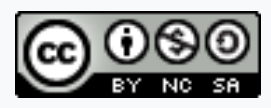

This work is licensed under a Creative Commons Attribution-NonCommercialShareAlike 4.0.

To cite this article:

Historein, H. (2004). Elli Scopetea (1950-2002) Member of the Academic Board of Historein. Historein, 4, 229. https://doi.org/10.12681/historein.93 


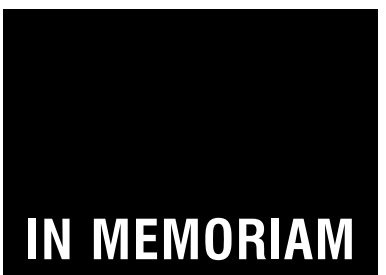

\section{Elli Scopetea (1950-2002) \\ Member of the Academic Board of Historein}

In 2002 a warm, witty, and humorous woman, who also happened to be one of the most gifted intellectual and cultural historians of the Balkans, passed away. Elli Scopetea belonged to the generation that reshaped Greek historiography in the 1980s, and she defied stereotypes more than most of her colleagues. Combining inquisitiveness with erudition and sensitivity, and attuned to complexity and nuance rather than simplification, she gave us fine and original images of the nineteenth century mental processes through which the "Near East," as it was then called, was transformed into a peculiar part of the notional "West."

She was ideally placed for this, as she could read and speak all Balkan languages except Albanian and Romanian, in addition to other European languages. She died while synthesizing the labors of her painstaking research, but she has left us indispensable works of the intellectual and

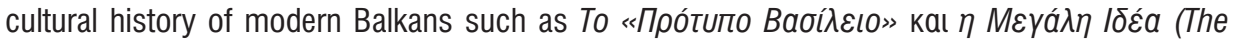

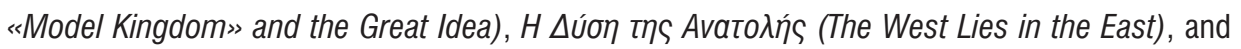

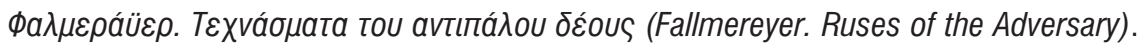

Her intellectual daring was underpinned by social and political radicalism. Any attempt to comprehend the past was, for her, part of a wider quest for self-realization pursued in the best spirit of the sixties, the decade in which she grew up. From the seventies, the years she created her own personal identity, Elli kept her love for soul music and good wine, bohemian living, and her talent for friendship. Her virtues sometimes counted as vices in conservative circles. Hence, Elli Scopetea was too superior a person to care about that. It is only regrettable she was not given the time to complete her work. Historein acknowledges the privilege of having Elli Scopetea onboard in its first steps and deeply mourns her loss. 